\title{
POTENTIAL INHIBITION OF GLYCATION AND FREE RADICAL SCAVENGING ACTIVITIES OF PURPLE SWEET POTATO EXTRACTS
}

\author{
POTENCIAL INIBIÇÃO DA GLICAÇÃO E SEQUESTRO DE RADICAIS LIVRES DE \\ EXTRATOS DE BATATA DOCE ROXA
}

\author{
I Nyoman SUARSANA ${ }^{\mathbf{1}^{*}}$; Iwan Harjono UTAMA ${ }^{\mathbf{1}}$ I Putu Gde Yudhi ARJENTINIA ${ }^{\mathbf{1}}$; \\ I Made KARDENA ${ }^{2}$
}

1. Laboratory of Biochemsitry, 2. Laboratory of Phatobiology, Faculty of Veterinary Medicine, Udayana University. Jln. P.B. Sudirman Denpasar, Bali, Indonesia 80233. suarsana65@yahoo.com

\begin{abstract}
Purple sweet potato (PSP) contains antioxidant compounds and it can be used to prevent oxidative damage to cellular components of human body. The research purpose is to find out the potential of PSP extract on inhibiting glycation process and free radicals scavenging activities. Purple sweet potato was extracted using ethanol 25, 50, and 75\% (PSP25, PSP50, PSP75) and then it was analyzed for free radical scavenging activities and antiglycation in forming advanced glycation end products (AGEs) using spectrophotometric method. Then all the collected data were examined with one-way ANOVA $(\mathrm{p}<0.05)$. The results showed that PSP extract has antioxidant activities and antiglycation properties. Based on IC50 values, PSP75 extract has a lower IC50 value compared to PSP25 and PSP50 (P $<0.05)$ and has better activity in scavenging DPPH, hydroxyl, and superoxide radicals. This potentiality was shown by the $\mathrm{IC}_{50}$ value of each PSP extract. The value of $\mathrm{IC}_{50}$ of scavenging DPPH radical acitivity for PSP25, PSP50, PSP75 extracts was respectively $281.08,254.94$, and $241.30 \mu \mathrm{g} / \mathrm{mL}$. The value of $\mathrm{IC}_{50}$ scavenging hydroxyl radicals was respectively $1.03,088$, and $0,79 \mathrm{mg} / \mathrm{mL}$, and the $\mathrm{IC}_{50}$ value of scavenging radicals of superoxide anion was respectively $1.10,0.97$, and $0.82 \mathrm{mg} / \mathrm{mL}$. The absorbance value of PSP75 in the BNT test and Fluorescence intensity are lower than PSP25 and PSP50, so that PSP75 extract is better at inhibiting glycation reaction. It can be concluded that the PSP extract has the potential in the inhibition of the glycation reaction and in the activity of elimination of free radicals (DPPH, hydroxyl, and superoxide radicals).
\end{abstract}

KEYWORDS: Antiglycation. Antioxidant. Free radicals. Purple sweet potato.

\section{INTRODUCTION}

Oxidative process has been much discussed lately as it relates to the formation of free radicals associated with many degenerative diseases. A degenerative disease is a medical term to describe an emerging disease caused by free radicals that cause degeneration of the normal cell function. Various degenerative diseases caused by oxidative damage include diabetes, atherosclerosis, osteoporosis, menopause, strokes, heart disease, and cancer (LEE et al., 2007; OZEN et al., 2011)

Metabolic reactions in cells, besides producing energy, also produces continuously free radicals (DROGE, 2002). In biochemical terms, the hydroxyl radical, and superoxide anion are generated through energy metabolism reactions involving oxygen. According to KREGEL and ZHANG (2007), if the amount of free radicals in the body exceeds the ability of antioxidants, it can lead to oxidative stress. This condition results in pathological effects on cells, thereby reducing the function of the cells, and decreasing intracellular antioxidant enzyme levels.

Oxidative stress in addition to lead lipid peroxidation and the formation of malondialdehyde (MDA), it also initiates the glycation reaction.
Glycation reaction is also known as Maillard reaction or non-enzymatic glycation reaction of proteins. Maillard reaction is a reaction between carbonyl group of carbohydrates and protein amino groups (GERRAD, 2002). Non-enzymatic glycation reaction of proteins causes the formation of AGEs products. It can cause tissue damage through modification of the protein structure and formation of free radicals (SEMBA et al., 2010 ).

AGEs products and free radicals have a function initiating onset of degenerative diseases, especially complications of diabetic, microvascular disease, kidney, nerve and pancreas (BROWNLEE, 2001). Glycation and oxidation reactions can contribute to accelerating aging and cellular damage (WELLS-KNECHT et al., 1995).

PSP is one of the food crops that have bioactive compounds anthocyanin for health. Anthocyanin is flavonoid polyphenol that is intensively researched both in terms of production (MERVAT at al., 2009), as well as the physiological function (YAMAKAWA; YOSHIMOTO, 2002). Research into the composition of anthocyanins in purple sweet potato has been widely studied (GODA et al., 1997; STEED; TRUONG, 2008). The results reported that the different varieties of sweet potato are dominated by the pigments in the 
form of acylated anthocyanins. Since 15 years ago, there has been an increased interest in research on the potential health benefits of anthocyanins (GIUSTI; WROLSTAD, 2003). Health benefits of anthocyanins and molecular mechanisms have been reported by LI et al., (2017). Their health beneficial effects have been documented in many in vivo and in vitro studies, involving activities such as anticancer activities, anti-inflammatory activities, neuroprotective activities, cardiovascular disease prevention activities, anti-obesity and antidiabetic activities, and other health benefits

The objective of the research was to determine the potential of the PSP extract in the inhibition of the glycation reaction and in the activity of elimination of free radicals. These properties can add value to the use of PSP extract as a free radical and AGE deterrent, favoring the reduction of premature cell aging and the prevention of degenerative diseases.

\section{MATERIALS AND METHODS}

\section{Preparation of PSP extracts}

The making of PSP extracts was conducted based on the method by OZEN et al., (2011). The raw material of PSP was thinly sliced and dried for 2 days at the temperature of $50^{\circ} \mathrm{C}$ in an oven. Then it was crushed in a mortar until it became simplicia (flour). $10 \mathrm{~g}$ of PSP was extracted with $250 \mathrm{~mL}$ ethanol concentration of $25 \%, 50 \%$ and $75 \%$, respectively mixed with magnetic strirer and idle for 2 hours. Each supernatant was filtered with Whatman 1. Separated solvents were then concentrated by vacuum evavorator at $40^{\circ} \mathrm{C}$ to obtain a concentrated extract, namely PSP25, PSP50, and PSP75. All the concentrated extracts was stored at $4^{\circ} \mathrm{C}$ in a plastic bottle and until they were ready for use.

\section{DPPH Radical Scavenging Activity Assay}

The DPPH radical scavenging activity assay was measured by the method of WU et al., (2003). A total of $2 \mathrm{~mL}(25-500 \mu \mathrm{g} / \mathrm{mL})$ sample was put into $2 \mathrm{~mL}$ DPPH $(0.15 \mathrm{mM})$ that dissolved in ethanol (95\%) and homogenized by vortex and then left in room temperature for 30 minutes. After that, the absorbance was read at $517 \mathrm{~nm}$ against a blank. The positive control used vitamin C $(25-500$ $\mu \mathrm{g} / \mathrm{mL})$. Scavenging activities were calculated by the equation:

Scavenging Activity $(\%)=\lceil$ Abs DPPH sample - Abs control sample] x $100 \%$

Abs blank

\section{Hydroxyl Radical Scavenging Activity Assay}

The analysis of hidroxyl scavenging activities was measured with the method of SUN et al., (2009). $1 \mathrm{~mL}$ sample of PSP25, PSP50, and PSP75 $(1 \mathrm{mg} / \mathrm{mL})$ was respectively added with a solution of $1 \mathrm{ml}$ phenantroline of $5 \mathrm{mM}$ in buffer phosphate $\mathrm{pH} 7.4(50 \mathrm{mM}), 0.1 \% \mathrm{H}_{2} \mathrm{O}_{2}$ of $0.5 \mathrm{ml}$, and $\mathrm{FeSO} 4(7.5 \mathrm{mM})$ of $0.5 \mathrm{ml}$, then put into the incubator at $37^{\circ} \mathrm{C}$ for 1 hour. The absorbances were read at $\lambda 510 \mathrm{~nm}$ (A1). The value of absorbance (A2) would be obtained if the sample were substituted with distilled water, and the value of absorbance (A3) would be obtained if the sample and $\mathrm{H}_{2} \mathrm{O}_{2}$ were replaced by distilled water. As a positive control, vitamin $\mathrm{C}$ (0.2 to $1.2 \mathrm{mg} / \mathrm{ml})$ was used. The percentage of scavenging was measured with the following equation: A2) $x 100 \%$

Effect of scavenging $(\%)=(\mathrm{A} 1-\mathrm{A} 2) /(\mathrm{A} 3-$

\section{Superoxide Anion Scavenging Activity Assay}

The scavenging activity of superoxide anion was measured based on the method described by WANG AND LUO (2007). $1 \mathrm{ml}$ sample of PSP25, PSP50, and PSP75 was respectively added with a solution of tris- $\mathrm{HCl}$ buffer $5.4 \mathrm{ml}(16 \mathrm{mM}, \mathrm{pH} 8)$; and 1, 2, 3-phentriol $(0.3 \mathrm{ml}, 0.6 \mathrm{mM})$, at a temperature of $25^{\circ} \mathrm{C}$, for about three minutes, $0.1 \mathrm{ml}$ of $5 \%$ ascorbic acid was added to stop the reaction. The absorbance was read on $\lambda 325 \mathrm{~nm}$ (A2). As a positive control, vitamin $\mathrm{C}(0.2$ to $1.2 \mathrm{mg} / \mathrm{ml})$ (A1) was used. The capability of scavenging superoxide anion was expressed by the following formula:

Scavenging effect $(\%)=(\mathrm{A} 1-\mathrm{A} 2) / \mathrm{A} 1 \mathrm{x}$ $100 \%$

\section{Reaction of Non-Enzymatic Protein Glycation}

The experiment were performed based on method of WU et al., (2009). A total of $10 \mathrm{ml}$ bovine serum albumin (BSA) $(20 \mathrm{mg} / \mathrm{ml})$ was added with sodium azide $(0.02 \%)$ in $\mathrm{pH} 7.4$ buffer phosphate and glucose of $5 \mathrm{ml}(500 \mathrm{mM})$. Each of the $5 \mathrm{mg}$ of PSP25, PSP50, and PSP75 extracts was added in phosphate buffer $(5 \mathrm{ml}, 200 \mathrm{mM}) \mathrm{pH}$ 7.4. Sample of $1 \mathrm{ml}$ was taken and mixed with a solution that was made previously and incubated for 20 days at $37^{\circ} \mathrm{C}$ to get at glycated products. As positive control, aminoguanidine was used. Glycation products was taken from the reaction system from day 0 ; day 2; day 5; day 10 , day 15 ; and day 20 for further analysis. 


\section{Analysis of Nitro-Blue Tetrazolium (NBT) Reductive Test}

NBT reduction of procedure assay used the method by BAKER et al., (1994). A total of $0.5 \mathrm{ml}$ glycation product, $0.3 \mathrm{mM}$ NBT solution $(2 \mathrm{ml})$ in $\mathrm{Na}_{2} \mathrm{CO} 3$ buffer $(\mathrm{pH} 10.35,100 \mathrm{mM})$, and then incubation at $25^{\circ} \mathrm{C}$ for 15 minutes. The absorbances were measured at $\lambda 530 \mathrm{~nm}$. The absorbance values on Y axis were plotted with day 0 ; day 2; day 5; day 10; day 15 , and day 20 on the $X$ axis. The lower the absorbance values the better the capability of sample of inhibiting the forming of AGEs.

\section{Statistical Analysis}

The data were displayed as mean. Data were calculated by ANOVA $(\mathrm{P}<0.05)$. It was processed by using a SPSS software version 20. In addition, the data were also displayed in graphical forms

\section{RESULTS}

The capability of PSP extract and vitamin C (as a control) in scavenging DPPH, radical of hydroxyl, and radical of superoxide anion was conducted. In general, the capasbility of PSP75 in inhibiting DPPH, radicals of hydroxyl and radicals of superoxide anion was significantly higher ( $P$ $<0.05)$ compared with PSP50 and PSP25, as shown in Table 1.

Table 1. Antioxidant and scavenging activity extract of PSP

\begin{tabular}{lccc}
\hline Sample & \multicolumn{3}{c}{$\mathrm{IC}_{50}$ activity of scavenging } \\
\cline { 2 - 4 } & $\mathrm{DPPH}(\mu \mathrm{g} / \mathrm{mL})$ & Hydroxyl $(\mathrm{mg} / \mathrm{mL})$ & Superoxide Anion $(\mathrm{mg} / \mathrm{mL})$ \\
\hline Vitamin C & $44.93 \pm 1.63 \mathrm{a}^{*}$ & $0.44 \pm 0.03 \mathrm{a}$ & $0.51 \pm 0.03 \mathrm{a}$ \\
PSP25 & $281.08 \pm 7.88 \mathrm{~d}$ & $1.03 \pm 0.04 \mathrm{~d}$ & $1.10 \pm 0.02 \mathrm{~d}$ \\
PSP50 & $254.94 \pm 3.57 \mathrm{c}$ & $0.88 \pm 0.03 \mathrm{c}$ & $0.97 \pm 0.02 \mathrm{c}$ \\
PSP75 & $241.30 \pm 2.39 \mathrm{~b}$ & $0.79 \pm 0.02 \mathrm{~b}$ & $0.82 \pm 0.03 \mathrm{~b}$ \\
\hline
\end{tabular}

*Different letter within same column shows significantly differences $(\mathrm{P}<0.05)$

DPPH test was used for a source of free radicals to measure compounds that can reduce free radicals. Analysis of antioxidant activities by DPPH test showed that the PSP extracts was capable of neutralizing the radical originating from DPPH $(1,1-$ diphenyl-2-pycryl hydrazyl) in a solution indicated by the fading colour of the tested solution.

In this experiment, the activity results of DPPH radical reduction by PSP extracts was compared with vitamin $\mathrm{C}$ as standard control. The scavenging activity of PSP extract has a potent antioxidant activity by the increasing concentration of the extract. The best antioxidant activity was shown in the PSP75 extract. The inhibition percentage of PSP75 $(500 \mu \mathrm{g} / \mathrm{ml})$ was $81.27 \%$, while the activity of scavenging vitamin $\mathrm{C}$ at the same level was $94.03 \%$. The $\mathrm{IC}_{50}$ value of PSP75 was found in the concentrations of $241.30 \mu \mathrm{g} / \mathrm{mL}$ (Table 1).

The extract of PSP and vitamin C was shown to inhibit hydroxyl radicals. The percentage of reduction of hydroxyl radicals increased in line with the increasing of the level of PSP extract. The potential reduction of PSP75 extracts against hydroxyl radical was better than the extracts of PSP25 and PSP50. In this study, the activity of scavenging of hydroxyl by PSP75 at $1.2 \mathrm{mg} / \mathrm{ml}$ was found at $72.55 \%$. Ascorbic acid at the same concentration showed inhibition of hydroxyl radicals of $87.79 \%$. The $\mathrm{IC}_{50}$ value for PSP75 was almost twice as much as the standard $\mathrm{IC}_{50}$ values, i.e. respectively found at 0.79 and $0.44 \mathrm{mg} / \mathrm{mL}$.

The activity of PSP extract in reducing superoxide radical showed an increased activity along with increasing doses of extract. The extract of PSP75 at $1.2 \mathrm{mg} / \mathrm{ml}$ showed the scavenging activity of $71.71 \%$. The ascorbic acid at the same level had an inhibition percentage of $85.77 \%$. $\mathrm{IC}_{50}$ value of scavenging activity by PSP75 was at 0.82 $\mathrm{mg} / \mathrm{ml}$, while vitamin $\mathrm{C}$ was found at $0.51 \mathrm{mg} / \mathrm{ml}$ (Table 1).

The inhibitory activity assay results of the PSP extract on the formation of glycation or AGEs through the test of NBT (nitro blue tetazolium) and test of fluorescence intensity on the formation of glycation system are presented in Figure 1 and 2.

The glycation products or AGEs in the glycation treatment (as a negative control) increased with the increasing time of incubation period that is characterized by high absorbance values (Figure 1). Extract of PSP was able to reduce the formation of glycation with increasing doses of the PSP extract. Extract of PSP75 had a better activity of inhibiting the formation of glycation when it was compared with PSP25 and PSP50. However, the inhibitory activity of glycation by aminoguanidine is the 
positive control used as the standard was still better

than the extract of PSP75.

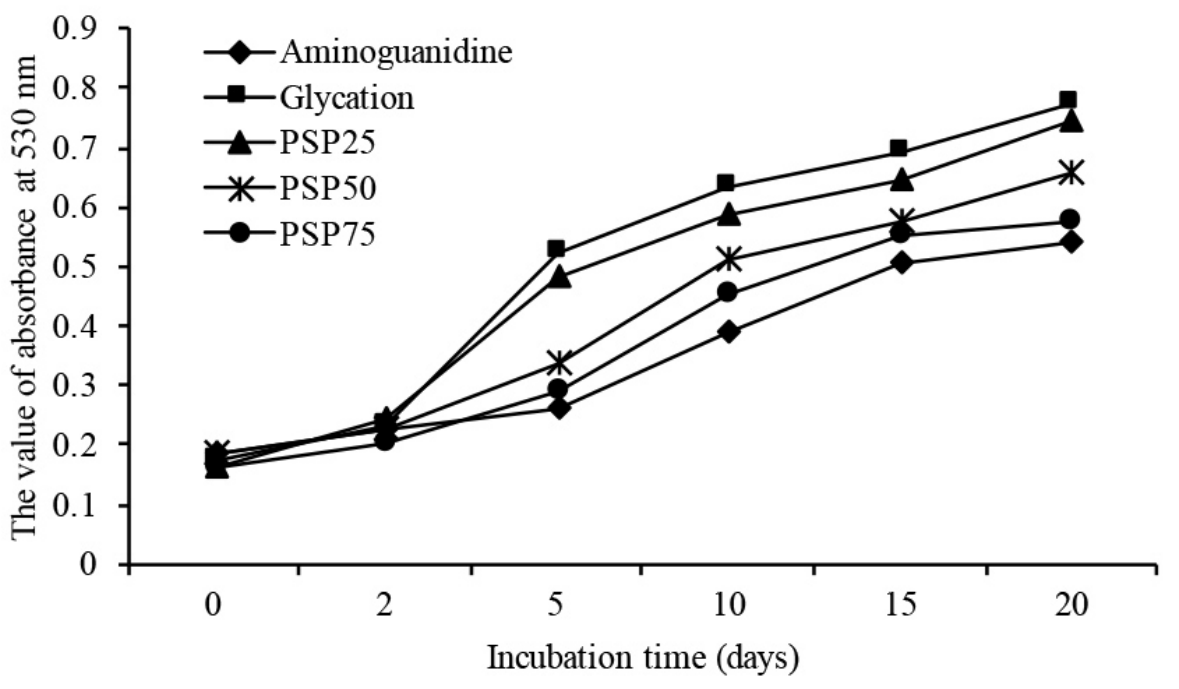

Figure 1. Inhibitory effect of PSP extract on the formation of AGEs by NBT reductive test

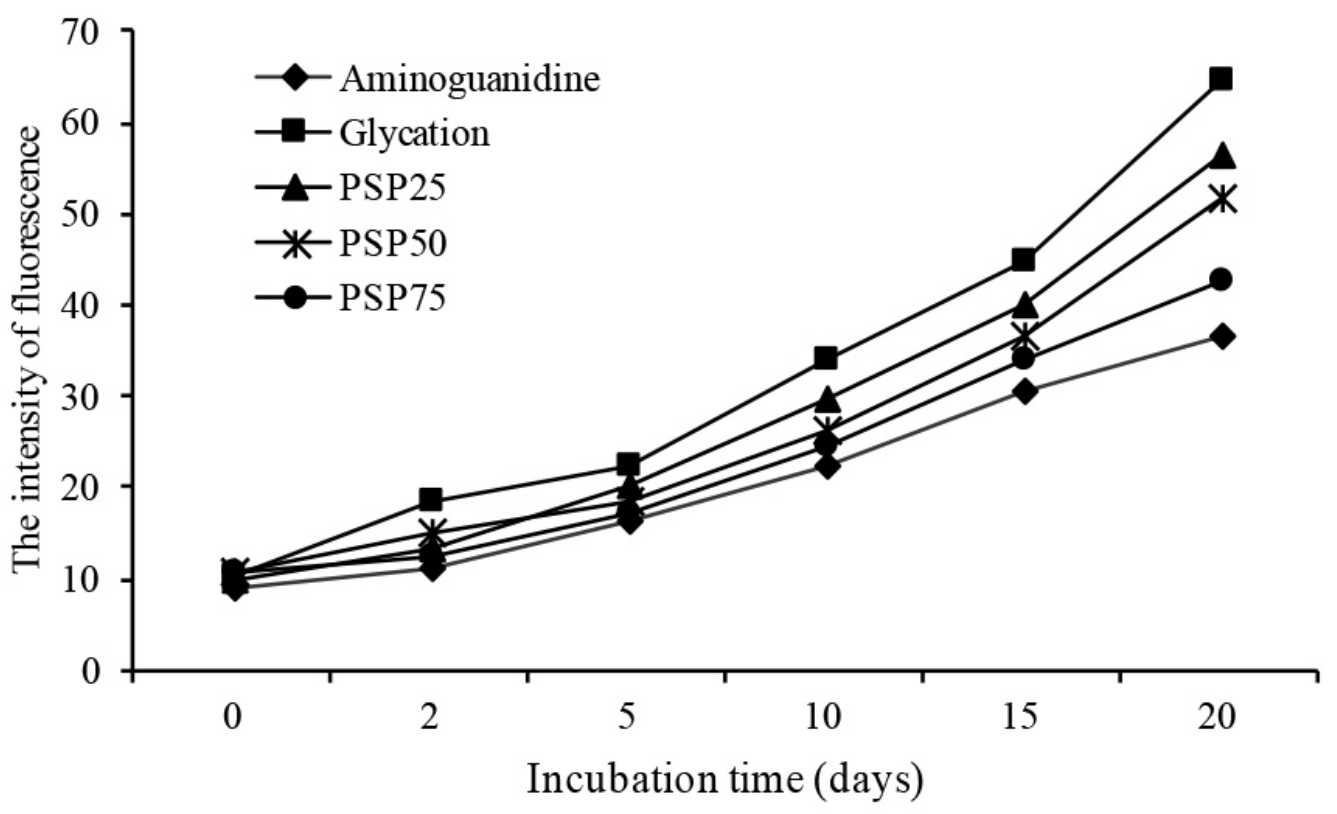

Figure 2. Inhibitory effect of PSP extract on the formation of AGEs by fluorescence intensity of BSA in various glycation sistems

In Figure 2, the effect of PSP extract and aminoguanidine as a positive control in inhibiting the formation of AGEs. After 20 days of incubation, the intensity of the fluorescent of glycation products was higher when compared to the positive control of aminoguanidine and PSP extracts. Fluorescent intensity value decreased with the increasing concentration of the PSP extract. This clearly shows that the addition of PSP extract and aminoguanidine is the positive control may inhibit the formation of glycation which is marked by the decline in the intensity of the fluorescent.

\section{DISCUSSION}

In the study, the PSP extract (PSP25PSP75) showed activity as antioxidant and antiglycation. The results indicate that the invitro test of PSP ethanol extract has the activity of elimination of free radicals and the inhibition of the glycation reaction. Therefore, the PSP extract needs to continue the invivo test in an attempt to analyze 
the ability to prevent cell damage due to free radicals, which are produced by in the body or those coming from outside the body. According to VALKO et al., ( 2007) free radicals can come from outside and from inside the body. Free radicals that come from the body are the result of enzymatic reactions of metabolism that include: superoxide anion $\left(\mathrm{O}_{2}{ }^{-}\right)$, hydroxyl $\left(\mathrm{HO}^{\bullet}\right)$, peroxyl, hydrogen peroxide $\left(\mathrm{H}_{2} \mathrm{O}_{2}\right)$, singlet oxygen $\left({ }^{1} \mathrm{O}_{2}\right)$, nitric oxide, and peroxynitrite

The ability of PSP extract in scavenging the DPPH free radical, hydroxyl ion, and superoxide anion was analyzed. The Extract of PSP were able to also prevent the forming of AGEs. At the same concentration, the extract of PSP75 was better than PSP25 and PSP50 in scavenging the activity of free radicals and also in inhibition of the glycation reaction. The extract of PSP75 has the $\mathrm{IC}_{50}$ value for DPPH of $241.30 \pm 2.39 \mu \mathrm{g} / \mathrm{mL}, \mathrm{IC}_{50}$ value for the hydroxyl $0.79 \pm 0.02 \mathrm{mg} / \mathrm{mL}$, and the $\mathrm{IC}_{50}$ value for superoxide anion $0.82 \pm 0.03 \mathrm{mg} / \mathrm{mL}$. According to PARK et al., (2010), the PSP ethanol extract has a 100-fold antioxidant activity when compared to the PSP water extract. However, the results of this study is quite similar to my past study which also evaluated that PSP ethanol extract has a high antioxidant activity.

Glycation products or AGEs are products of the process of glycation. Glycation reaction is also known as Mailard reaction, namely the reaction that occurs between free amino acid groups of protein and the group of carbonyl from sugars in reducing the production of advanced Maillard products or AGEs (BROWNLEE, 2001). In the human body, the formation of AGEs not only causes damages directly to the cells but also produces free radicals (ROBERTSON et al., 2004). The free radicals produced by the reaction of glycation can initiate cell damage through a mechanism of lipid peroxidation.

The result of free radical chain reaction with cell biomolecules can cause physiological disorders up to cell and tissue death (YOU et al., 2011). In addition, according to HANCOCK et al., (2001), free radicals can induce programed cell death, even inducing or suppressing the expression of many genes that can affect the body's physiological system. Therefore, PSP extract with high antioxidant potency is capable of being a reactive oxygen species (ROS) scavenger and has the ability to inhibit glycemic reactions. This potential is very important to prevent oxidative damage, and inhibit the chain reaction so as to prevent premature aging of the body's cells.
The extract of PSP has the ability to inhibit oxidation process and glycation reaction. Therefore, the characteristics of PSP extract as anti-oxidant and anti-glycation are important to be highlighted as the glycation products or AGEs which can cause direct negative impact to the body' cells as well as produce free-radicals. In a test of free radicals, the percentage inhibition to DPPH radicals was significantly increased $(\mathrm{P}<0.05)$ with increasing levels of PSP extract. Reduction of DPPH to be DPPH-H resulted in discoloration of the reagent of DPPH, from purple to yellow. The presence of antioxidants in the sample was able to neutralize ion of $\mathrm{DPPH}^{\bullet}$ by the transfer of electrons or hydrogen atoms (MENAGA et al., 2013). Furthermore, DPPH radicals that received electrons formed a stable molecule (KADAM et al., 2010). In accord with Sreeyan and Rao (1996) and Menaga et al., (2013), the principle of DPPH reduction of free radicals was antioxidants that reacted with free radicals of DPPH and convert into 1, 1-diphenyl-2-picryl hydrazine.

Superoxide radicals are highly toxic oxygen species, produced by many reactions of photochemical and biological (GOVINDARAJAN et al., 2003). Superoxide radicals interact with other molecules. The result of such a reaction could produce secondary radicals, for example singlet oxygen, hydrogen peroxide, and hydroxyl through enzymatic reactions and metal catalyst processes. In this study, the PSP extract was found to effectively reduce DPPH radical, hydroxyl ion, and superoxide anion.

Between free radicals, hydroxyl radicals are the most dangerous because they have a very high reactivity capable of getting into the DNA molecule. This is a very high reactivity according to BUETTNER (1993), because the hydroxyl radical $\left(\mathrm{HO}^{\circ}\right)$ has a high electron potential value that is equal to $2310 \mathrm{E}^{0_{1}} / \mathrm{mV}(\mathrm{pH})$, the highest among the order of free radicals while the superoxide anion $\left(\mathrm{O}_{2}{ }^{\circ}\right)$ has a potential value of 940 electron of 940 $\mathrm{E}^{\mathrm{O}^{1} / \mathrm{mV}}(\mathrm{pH})$. Hydroxyl radicals can damage three important compounds that serve to maintain the integrity of the cell, i.e. proteins, lipids, and DNA (VALKO et al., 2007).

Organisms develop a series of defense mechanisms against exposure to free radicals. The mechanism includes (a) preventive mechanisms, (b) repairing mechanisms, (c) physical defense, and (d) antioxidant defenses. As for the antioxidant defenses, the cell organisms have a natural defense system against free radicals called endogenous antioxidant enzymes. Antioxidant enzymatic defenses include superoxide dismutase (SOD), glutathione peroxidase (GPx), glutathione reductase 
(GRx), and catalase (CAT) (VALKO et al., 2007; RAO et al., 2011).

The mechanism of action of antioxidant enzymes protects cell components against free radicals. Among them, the SOD plays a role in catalyzing superoxide anion $\left(\mathrm{O}^{-}\right)$to hydrogen peroxide $\left(\mathrm{H}_{2} \mathrm{O}_{2}\right)$ and oxygen molecules $\left(\mathrm{O}_{2}\right)$. It is the body's primary defense as it prevents further generation of free radicals. Catalase and glutathione peroxidase detoxify the reactive oxygen radicals by catalyzing the formation of $\mathrm{H}_{2} \mathrm{O}_{2}$ into water $\left(\mathrm{H}_{2} \mathrm{O}\right)$ and oxygen molecules $\left(\mathrm{O}_{2}\right)$. Glutathione reductase, a flavoprotein enzyme, regenerates GSH from GSSG (oxidized glutathione), with NADPH as a source of reducing power. (HALLIWEL, 2006; PHAM-HUY et al., 2008; RAO et al., 2011)

In normal cells there is a balance between the formation and removal of free radicals. If free radicals are excessive or when the levels of endogenous antioxidant enzymes are reduced, this condition is referred to as oxidative stress. Therefore, exogenous antioxidant intake is necessary in conditions of oxidative stress. One of the non-enzymatic antioxidants represented by purple sweet potato extract is that it has a high antioxidant activity.

According to Zhang et al., 2011, antioxidation and anti-glycation properties of polysaccharides from Misgurnus anguillicaudatus showed that the extract was effective in preventing diabetic complications. PSP extract with strong antioxidant ability can be used as antiatherosclerotic and anti-diabetic agents (YOU; ZHAO, 2011) and reduce the risk of cardiovascular disease (MAZZA, 2007). Anthocyanin compounds have strong antioxidant activities and may be chemo-protective so they can be utilized to improve health (GIUSTI; WROLSTAD, 2003).

Anthocyanin compounds in the purple sweet potato have strong antioxidant activity as free radical scavenging and in the inhibition of the glycation reaction. So that anthocyanin has been widely applied in many aspects for biological and health functions. The immunomodulatory effects of diet supplement of purple sweet potato extract on mice (KIM et al., 2015), the hepatoprotective activity of anthocyanin-rich purple sweet potato extract was demonstrated by WANG et al., (2017) and anthocyanin have cancer-preventive properties in the mouse model (ASADI et al., 2017).

Provision of exogenous antioxidants is an attempt to reduce the process of free radical formation or prevent chain reaction of free radicals and to prevent cell damages. Some compounds derived from plants, which are especially rich in antioxidants, can be a source of exogenous antioxidants, and one of them being PSP. The PSP has a pigment known as anthocyanin. Anthocyanin is a polyphenol flavonoid (MERVAT et al., 2009) and has a strong activity of antioxidant (PARK et al., 2010; LAKSMIANI et al., 2016). So anthocyanin can be used to improve health and is preventive to diseases.

This research results will surely contribute to the practical knowledge in the field of nutraceuticals for the potential of anti-oxidant and anti-glycation of the purple sweet potato. Oxidative process and premature aging cells are the main problems for many people and it is highly likely that more and more people are getting concerns about this. So, this research will become groundwork in the future for its benefits. However, a further study on mechanism of anti-oxidant and anti-glycation in purple sweet potato as well as its in vivo research, including in humans, are really needed.

\section{CONCLUSION}

Ethanolic extracts of purple sweet potato have strong antioxidant activity as free radical scavenging and in the inhibition of the glycation reaction. In adidtion, they showed dose-dependent anti-oxidant and antigenic properties.

\section{ACKNOWLEDGEMENTS}

We would like to thank the Directorate General of Higher Education, Ministry of Research, Technology and Higher Education, which has funded the research "Hibah Fundamental" (Grant No:311-118 /UN14.2/ PNL.01.03.00/15). We also express our thanks to I Nyoman Udayana of the Udayana University Language Laboratory for having proofread the draft of this paper.

RESUMO: Batata-doce roxa (PSP) contém compostos antioxidantes e pode ser usada para prevenir o dano oxidativo aos componentes celulares do corpo humano. O objetivo da pesquisa é descobrir o potencial do extrato de PSP na inibição do processo de glicação e atividades de eliminação de radicais livres. A batata-doce roxa foi extraída usando etanol 25, 50 e 75\% (PSP25, PSP50, PSP75) e, em seguida, foi analisada quanto a atividades de eliminação de radicais livres e antiglicação na formação de produtos finais de glicação avançada (AGEs) usando método espectrofotométrico. Em seguida, todos os dados coletados foram examinados com uma análise de variância simples (one-way ANOVA) (p <0,05). 
Os resultados mostraram que o extrato de PSP possui atividade antioxidante e propriedades antiglicantes. O extrato de PSP75 apresentou a maior atividade de eliminação dos radicais DPPH, hidroxila e superóxido significativamente maiores $(\mathrm{P}<0,05)$ que os extratos PSP25 e PSP50. Esta potencialidade foi demonstrada pelo valor de IC50 de cada extrato de PSP. O valor de IC50 da atividade de eliminação do radical DPPH para os extractos PSP25, PSP50, PSP75 foi respectivamente de 281,08, 254,94 e 241,30 g/mL. O valor IC50 dos sequestrantes dos radicais hidroxila foi, respectivamente, de 1,03, 088 e $0,79 \mathrm{mg} / \mathrm{mL}$, e o valor de IC50 dos radicais sequestrantes do superóxido foi, respectivamente, $1,10,0,97 \mathrm{e} 0,82 \mathrm{mg} / \mathrm{mL}$. Como antiglicante, o extrato de PSP75 tem uma capacidade melhor do que PSP25 e PSP50 em inibir produtos de AGEs. Pode-se concluir que o extrato etanólico PSP75 possui alta atividade antioxidante e potencial como antiglicante.

PALAVRAS-CHAVE: Antiglicação. Antioxidante. Radicais livres. Batata-doce roxa.

\section{REFERENCES}

ASADI, K.; FERGUSON, L. R.; PHILPOTT, M.; KARUNASINGHE, N. Cancer-preventive properties of an anthocyanin-enriched sweet potato in the APC (MIN) mouse model. J. Cancer Prev. v. 22, n. 3, p. 135-146, 2017. doi:10.15430/JCP.2017.22.3.135.

BAKER, J. R.; ZYZAK, D. V.; THRPEAND, S. R.; BAYNES, J. W. Chemistry of frutosamine assay: d-glucosone is the product of oxidation of amidori compounds. Clinical chemistry endocrinology and metabolism, v. 40, p. 1950-1955, 1994.

BROWNLEE, M. Biochemistry and molecular cell biology of diabetic complications. Nature, v. 414, p. 813-820, 2001. https://doi.org/10.1038/414813a

BUETTNER, G. R. The pecking order of free radicals and antioxidants: Lipid peroxidation, a-tocopherol, and ascorbate. Arch Biochem Biophys, v. 300, p. 535-543, 1993. https://doi.org/10.1006/abbi.1993.1074

DROGE, W. Free Radicals in the Physiological Control of Cell Function. Physiol Rev, v. 82, p. 47-95, 2002. https://doi.org/10.1152/physrev.00018.2001

GERRARD, J. A. New aspects of an ageing chemistry-recent developments concerning the Maillard reaction. Aust. J. Chem, v. 55, p. 299-310, 2001. https://doi.org/10.1071/CH02076

GIUSTI, M. M.; WROLSTAD, R. E. Acylated anthocyanins from edible sources and their application in food systems. Biochemical Enginering Journal, v. 14, p. 217-225, 2003. https://doi.org/10.1016/S1369-703X(02)00221-8

GODA, Y.; SHIMIZU, T.; KATO, Y.; NAKAMURA, M.; MAITANI, T.; YAMADA, T.; TERAHARA, N.; YAMAGUCHI, M. Two acylated anthocyanins from purple sweet potato. Phitochemistry, v. 44, p. 183-186, 1997. https://doi.org/10.1016/S0031-9422(96)00533-X

GOVINDARAJAN, R.; KUMAR, M. V.; RAWAT, A. K. S; SHANTA, M. Free radical scavenging potential of Picorrhiza kurroa Royle Ex Benth. Ind J Exp Bio, v. 41, p. 875-879, 2003.

HALLIWELL, B. Reactive spesies and antioxidants: Redox biology is a fudamental theme of aerobic life. Plant Phisiology, v. 141, p. 312-322, 2006. https://doi.org/10.1104/pp.106.077073

HANCOCK, J. T.; DESIKANAND, R.; NEILL, S. J. Role of reactive oxygen species in cell signaling pathways. Biochemical society Transactions, v. 29, p. 345-350, 2001. https://doi.org/10.1042/bst0290345

KADAM, V. J.; JOSHI, Y. M.; SAWANTAND, H. P; JADHAV, V. Free radical scavenging activity of aqueous solution of black Salt. Int J Pharmacy Pharm Sc, v. 2, p. 95-96, 2010.

KIM, O. K.; NAM, D. E.; YOON, H. G.; BAEK, S. J.; JUN, W.; LEE, J. Immunomodulatory and antioxidant effects of purple sweet potato extract in LP-BM5 murine leukemia virus-induced murine acquired immune deficiency syndrome. J Med Food. v. 18, n. 8, p. 882-889, 2015. doi: 10.1089/jmf.2014.3247 
KREGEL, K. C.; ZHANG, H. J. An integrated view of oxidative stress in aging: basic mechanisms, functional effects, and pathological considerations. Am J Physiol Regul Integr Comp Physiol, v. 292, p. R18-R36, 2007.

https://doi.org/10.1152/ajpregu.00327.2006

LAKSMIANI, N. P. L.; PARAMITA, N. L. P. V.; WIRASUTA, I. M. A. G. In vitro and In silico antioxidant activity of purified fractions from purple sweet potato ethanolic extract. Int J Pharm Pharm Sci, v. 8, n. 8, p. 177-181, 2016.

LEE, B.; KRISHNANCHETTIAR, S.; LATEEFAND, S. S.; GUPTA, S. Analyses of the in vitro non-enzymatic glycation of peptides/proteins by matrix-assisted laser desorption/ionization mass spectrometry. International journal of mass spectrometry, v. 260, p. 67-74, 2007. https://doi.org/10.1016/j.ijms.2006.07.005

LI, D.; WANG, P.; LUO, Y.; ZHAO, M.; CHEN, F. Health benefits of anthocyanins and molecular mechanisms: Update from recent decade. Critical Reviews in Food Science and Nutrition, v. 57, n. 8, p. 1729-1741, 2017. http://dx.doi.org/10.1080/10408398.2015.1030064

MAZZA, G. Anthocyanins and heart health. Anali dell’ Instituto Superiore di Sanita, v. 43, p. 369-374, 2007.

MENAGA, D.; RAJAKUMAR, S.; AYYASAMY, P. M. Free radical scavenging activity of methanolic extract of Pleurotus florida mushroom. Int J Pharm Pharm Sci, v. 5, p. 601-606, 2003

MERVAT, M. M.; FARAND, E; HANAN, A. A. Antioxidant Activities, Total Anthocyanins, Phenolics and Flavonoids Contents of Some Sweetpotato Genotypes under Stress of Different Concentrations of Sucrose and Sorbitol. Australian Journal of Basic and Applied Sciences, v. 3, p. 3609-3616, 2009.

OZEN, T.; DEMIRTASAND, I.; AKSIT, H. Determination of antioxidant activities of various extracts and essential oil compositions of Tymus paecox subsp. skorpilii var. skorpilii. Food Chemistry, v. 124, p. 58-64, 2011. https://doi.org/10.1016/j.foodchem.2010.05.103

PARK, K. H.; KIM, J. R.; LEE, J. S.; LEE, H.; CHO, K. H. Ethanol and water extract of purple sweet potato exhibits antiatherosclerotic activity and inhibits protein glycation. Journal of Medicinal Food, v. 13, n. 1, p. 91-98, 2010. https://doi.org/10.1089/jmf.2009.1077

PHAM-HUY, L. A.; HE, H.; PHAM-HUY, C. Free radicals, Antioxidants in Disease and Health. International Journal of Biomedical Science. v. 4, p. 89-96, 2008.

RAO, S. P.; KALVA, S.; YERRAMILLI, A.; MAMIDi, S. Free Radicals and Tissue Damage: Role of Antioxidants. Free Rad. Antiox, v. 1, p. 2-7, 2011. https://doi.org/10.5530/ax.2011.4.2

ROBERTSON, R. P.; HARMON, J.; TRAN, P. O.; POITOUT, V. $\beta$-Cell glucose toxicity, lipotoxicity, and chronic oxidative stress in type 2 diabetes. Diabetes, v. 53, p. S119-S124, 2004. https://doi.org/10.2337/diabetes.53.2007.S119

SEMBA, R. D.; NICKLETT, E. J.; FERRUCCI, L. Does accumulation of advanced glycation end products contribute to the aging phenotype. Journals of Gerontology A: Biological Sciences and Medical Sciences, v. 65, p. 963-975, 2010. https://doi.org/10.1093/gerona/glq074

SREEYAN, N.; RAO, M. Free radical scavenging activity of curcuminoids. Drug Res, v. 46, p. 169-171, 1996.

STEED, L. E.; TRUONG, V. D. Anthocyanin Content, Antioxidant Activity, and Selected Physical Properties of Flowable Purple-Fleshed Sweetpotato Purees. Journal Food Science, v. 73, p. S215-S221, 2008. https://doi.org/10.1111/j.17503841.2008.00774.x

SUN, L.; WANG, C.; SHI, Q.; MA, C. Preparation of different molecular weight polysaccharides from Porpyridium cruentum and their antioxidant activities. International journal of biological macromolecules, v. 45, p. 42-37, 2009. https://doi.org/10.1016/j.ijbiomac.2009.03.013

VALKO, M.; LEIBFRITZ, D.; MONCOL, J.; CRONIN, M. T. D.; MAZURA, M.; TELSER, J. Free radicals and antioxidants in normal physiological functions and human disease. Inter J Biochem \& Cell Biol, v. 39, p. 44-84, 2007. https://doi.org/10.1016/j.biocel.2006.07.001 
WANG, Z.; LUO, D. Extration, purification and antioxidant activities of polysaccharides from Dioscorea nipponica makino. Nature production research development, v. 19, p. 29-34, 2007.

WANG, L.; ZHAO, Y.; ZHOU, Q.; LUO, C. L.; DENG, A. P.; ZHANG, Z. C.; ZHANG, J. L. Characterization and hepatoprotective activity of anthocyanins from purple sweet potato (Imomea batatas L cultivar Eshu No.8). J Food Drug Anal. v.25, n.3, p.607-618, 2017. doi: 10.1016/j.jfda.2016.10.009.

WELLS-KNECHT, K. J.; ZYZAK, D. V.; LITCHFIELD, J. E.; THORPE, S. R.; BAYNES. Mechanism of Autoxidative Glycosylation: Identification of Glyoxal And Arabinose As Intermediates In The Autoxidative Modification of Proteins By Glucose. Biochemistry, v. 34, p. 3702-3709, 1995. https://doi.org/10.1021/bi00011a027

WU, H. C.; CHEN, H. M.; SHIAU, C. Y. Free amino acids and peptides as related to antioxidant properties in protein hydrolysates of mackerel (Scomber austriasicus). Food Research International, v.36, p.949-957, 2003. https://doi.org/10.1016/S0963-9969(03)00104-2

WU. J.; HSIEH, C.; WANG, H.; CHEN, H. Inhibitory effects of guava (Psidium guajava L) leaf extract nd its activity compounds on the glycation process of protein. Food Chemistry, v. 113, p. 78-84, 2009. https://doi.org/10.1016/j.foodchem.2008.07.025

YAMAKAWA, O; YOSHIMOTO, M. Sweet potato as food material with physiological functions. Acta Hort (ISHS), v. 583, p. 179-85, 2002. https://doi.org/10.17660/ActaHortic.2002.583.20

YOU, L.; ZHAO, M.; REGENSTEIN, J. M.; REN, J. In vitro acticity and in vivo anti-fatique effect of loach (Misgurnus anguillicaudatus) peptides prepared by papain digestion. Food Chemistry, v. 124, p. 188-194, 2011. https://doi.org/10.1016/j.foodchem.2010.06.007

ZHANG, L. S.; WANG, X.; DONG, L. L. Antioxidation and antiglycation of polysaccharides from Misgurnus anguillicaudatus. Food Chemistry, v. 124, p. 183-187, 2011. https://doi.org/10.1016/j.foodchem.2010.06.006 